\title{
Photochemical production of ozone in Beijing during the 2008 Olympic Games
}

\author{
C. C.-K. Chou ${ }^{1}$, C.-Y. Tsai ${ }^{1}$, C.-C. Chang ${ }^{1}$, P.-H. Lin $^{2}$, S. C. Liu ${ }^{1}$, and T. Zhu ${ }^{3}$ \\ ${ }^{1}$ Research Center for Environmental Changes, Academia Sinica, Taipei 11529, Taiwan \\ ${ }^{2}$ Department of Atmospheric Sciences, National Taiwan University, Taipei 10617, Taiwan \\ ${ }^{3}$ College of Environmental Sciences and Engineering, Peking University, Beijing 100871, China
}

Received: 3 May 2011 - Published in Atmos. Chem. Phys. Discuss.: 10 June 2011

Revised: 20 September 2011 - Accepted: 20 September 2011 - Published: 23 September 2011

\begin{abstract}
As a part of the CAREBeijing-2008 campaign, observations of $\mathrm{O}_{3}$, oxides of nitrogen $\left(\mathrm{NO}_{\mathrm{x}}\right.$ and $\left.\mathrm{NO}_{\mathrm{y}}\right), \mathrm{CO}$, and hydrocarbons (NMHCs) were carried out at the air quality observatory of the Peking University in Beijing, China during August 2008, including the period of the 29th Summer Olympic Games. The measurements were compared with those of the CAREBeijing-2006 campaign to evaluate the effectiveness of the air pollution control measures, which were conducted for improving the air quality in Beijing during the Olympics. The results indicate that significant reduction in the emissions of primary air pollutants had been achieved; the monthly averaged mixing ratios of $\mathrm{NO}_{\mathrm{x}}, \mathrm{NO}_{\mathrm{y}}$, $\mathrm{CO}$, and NMHCs decreased by $42.2,56.5,27.8$, and $49.7 \%$, respectively. In contrast to the primary pollutants, the averaged mixing ratio of $\mathrm{O}_{3}$ increased by $42.2 \%$. Nevertheless, it was revealed that the ambient levels of total oxidant $\left(\mathrm{O}_{\mathrm{x}}=\mathrm{O}_{3}+\mathrm{NO}_{2}+1.5 \mathrm{NO}_{\mathrm{z}}\right)$ and $\mathrm{NO}_{\mathrm{z}}$ were reduced by 21.3 and $77.4 \%$, respectively. The contradictions between $\mathrm{O}_{3}$ and $\mathrm{O}_{\mathrm{x}}$ were further examined in two case studies. Ozone production

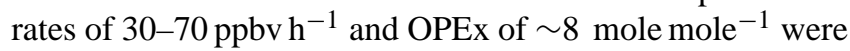
observed on a clear-sky day in spite of the reduced levels of precursors. In that case, it was found that the mixing ratio of $\mathrm{O}_{3}$ increased with the increasing $\mathrm{NO}_{2} / \mathrm{NO}$ ratio, whereas the $\mathrm{NO}_{\mathrm{z}}$ mixing ratio leveled off when $\mathrm{NO}_{2} / \mathrm{NO}>8$. Consequently, the ratio of $\mathrm{O}_{3}$ to $\mathrm{NO}_{z}$ increased to above 10 , indicating the shift from VOC-sensitive regime to $\mathrm{NO}_{\mathrm{x}}$-sensitive regime. However, in the other case, it was found that the $\mathrm{O}_{3}$ production was inhibited significantly due to substantial reduction in the NMHCs. According to the observations, it was suggested that the $\mathrm{O}_{3}$ and/or $\mathrm{O}_{\mathrm{x}}$ production rates in Beijing
\end{abstract}

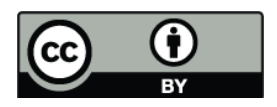

Correspondence to: C. C.-K. Chou (ckchou@ rcec.sinica.edu.tw) should have been reduced as a result of the reduction in the emissions of precursors during the Olympic period. However, the nighttime $\mathrm{O}_{3}$ levels increased due to a decline in the $\mathrm{NO}-\mathrm{O}_{3}$ titration, and the midday $\mathrm{O}_{3}$ peak levels were elevated because of the shift in the photochemical regime and the inhibition of $\mathrm{NO}_{\mathrm{z}}$ formation.

\section{Introduction}

Urbanization is undergoing worldwide, particularly in the developing countries. The intensive human activities unavoidably result in substantial emissions of air pollutants in urban areas. The anthropogenic compounds can react in the atmosphere and, consequently, lead to the formation and accumulation of secondary pollutants and cause further deterioration of air quality. Exposure to the air pollutants has been identified as one of the major health risks of the residents in megacities (Molina et al., 2004).

With a total population over 10 million, Beijing is one of the megacities in the world. The economic development has brought up the number of vehicles, factories, as well as power plants in the Beijing metropolitan area during the last two decades. As a result, Beijing has suffered from serious air pollution (Wang et al., 2006; An et al., 2007). Being the host city of the 29th Summer Olympic Games, the Beijing government setup rather aggressive action plans to reduce the emissions of air pollutants in Beijing and its surrounding areas during the Olympic period. In particular, the traffics were restricted temporarily to reduce the vehicular exhausts within the Beijing City (Wang et al., 2009a). Emission inventory studies indicated that the traffic emissions of volatile organic compounds (VOCs), carbon monoxide (CO),

Published by Copernicus Publications on behalf of the European Geosciences Union. 
nitrogen oxides $\left(\mathrm{NO}_{\mathrm{x}}\right)$, and particulate matters $\left(\mathrm{PM}_{10}\right)$ were reduced by $\sim 50 \%$ from their respective normal levels in Beijing (Zhou et al., 2010; Wang et al., 2010c). The estimates of $\mathrm{NO}_{\mathrm{x}}$ reduction are consistent with previous reports based on satellite observations, which indicated a reduction of $\sim 40$ $60 \%$ in the column density of $\mathrm{NO}_{2}$ over Beijing during the Olympic Games (Mijling et al., 2009; Witte et al., 2009). Besides, the reductions in the vehicular emissions of the other air pollutants have also been validated by a series of groundbased observations (Liu et al., 2009; Wang et al., 2009a, b, 2010a, b). Evidently, the air pollution control measures had successfully reduced the ambient levels of the primary air pollutants in Beijing during the Olympic Games.

In contrast to the substantial reduction of the primary air pollutants, the mitigation of ozone $\left(\mathrm{O}_{3}\right)$ in Beijing during the Olympic period was not as expected. Observations at a rural site showed that the monthly averaged daytime mixing ratio of $\mathrm{O}_{3}$ for August 2008 was reduced by $\sim 20 \%$, as being compared with the same month of 2006-2007 (Wang et al., 2009b). However, comparing the observations in Beijing downtown for periods before and after the traffic control indicated an increase of $16 \%$ in the mixing ratio of $\mathrm{O}_{3}$ (Wang et al., 2010b). The increases in the $\mathrm{O}_{3}$ mixing ratio were not consistent with the decreases in the emissions of precursors, i.e. $\mathrm{NO}_{\mathrm{x}}$ and VOCs. In particular, the ozone formation potentials (OFPs) of the non-methane hydrocarbons (NMHCs) had been reduced by $48 \%$ (Wang et al., 2010a). Wang and Xie (2009) attributed the inconsistency to the reduced $\mathrm{NO}-\mathrm{O}_{3}$ titration, which was a result of the reduction in $\mathrm{NO}_{\mathrm{x}}$ emissions. Wang et al. (2009b) suggested that the high $\mathrm{O}_{3}$ episodes in Beijing during August 2008 were mostly meteorology-driven. Wang et al. (2010b) argued that the transport of photochemical plumes from the surrounding areas to Beijing was the major contributor of the "peaks" of $\mathrm{O}_{3}$ in Beijing downtown. To date, the high $\mathrm{O}_{3}$ levels in Beijing during the Olympics are still an open issue.

The "Campaign for Air Quality Research in Beijing and Surrounding Region - 2008" (CAREBeijing-2008) is an intensive experiment for investigating the air quality in Beijing during the Olympic period and evaluating the effectiveness of the air pollution control measures. Furthermore, while the $\mathrm{O}_{3}$-precursors relationship was established mostly on theories and/or chamber studies, the air quality control program for the Beijing Olympics provided a unique opportunity to examine the response of ambient $\mathrm{O}_{3}$ level to a drastic reduction in the emissions of precursors. In this study, the measurements of $\mathrm{O}_{3}$ and its precursors carried out at the observatory on the campus of the Peking University are presented. The measurements are compared with those conducted in the summer of 2006, i.e. CAREBeijing-2006, to show the air quality effects due to the control measures. Moreover, the data are analyzed in terms of photochemistry to explain the disagreement between $\mathrm{O}_{3}$ and the primary air pollutants in Beijing during the 2008 Summer Olympics.

\section{Experimental methods}

To investigate the air quality and atmospheric chemistry in Beijing, an intensive observatory was setup on the campus of the Peking University (PKU) during the CAREBeijing-2008. The detailed geographic characteristics of this site have been presented in other papers of this special issue (e.g., Wang et al., 2010a) and, therefore, are not described here. A comprehensive set of instrument was installed at the PKU station to measure the concentrations of major air pollutants, with emphases upon ozone and aerosols. However, only the instruments relevant directly to this study will be outlined in the followings.

The measurements of nitric oxide (NO), nitrogen dioxide $\left(\mathrm{NO}_{2}\right)$, and total reactive nitrogen $\left(\mathrm{NO}_{\mathrm{y}}\right)$ were carried out concurrently with a time resolution of $1 \mathrm{~min}$. NO was measured using a chemiluminescence detector (Model 42C-TL, Thermo Scientific). $\mathrm{NO}_{2}$ was measured with a system consisting of a chemiluminescence detector (Model CLD 88p, ECO Physics) and a photolytic converter (Model PLC 860, ECO Physics). The efficiency of the converter kept at $\sim 66 \%$ throughout the campaign, which was determined with gas titration method. $\mathrm{A} \mathrm{NO}_{\mathrm{y}}$ converter (ECO Physics) was employed to reduce the $\mathrm{NO}_{\mathrm{y}}$ species to $\mathrm{NO}$ with $\mathrm{CO}$ on the surface of a gold tube at $300^{\circ} \mathrm{C}$. Then, the second CLD 88p detector was used for quantification of $\mathrm{NO}_{\mathrm{y}}$. The efficiency of this converter was $\sim 100 \%$, which was checked by $\mathrm{HNO}_{3}$ measurement in laboratory before the field experiment and is consistent with the literatures (e.g., Fehsenfeld et al., 1987). Daily calibration of the chemiluminescence detectors was accomplished using 0.5-200 ppbv NO, which was generated by dilution of 10 ppmv standard NO (Scott Specialty Gases, USA) with NO-free air from an in-situ zero-gas generator (Model PAG003, ECO Physics). The detection limits of the instruments were estimated by 3 times the standard deviation of the signals of zero-air measurements, which were $0.3,0.1$, and $0.3 \mathrm{ppbv}$ for $\mathrm{NO}, \mathrm{NO}_{2}$, and $\mathrm{NO}_{\mathrm{y}}$, respectively.

For in-situ measurement of hydrocarbons (65 species, as listed in Table 1), ambient air was analyzed by an automated GC/MS/FID (Varian CP-3800 and Saturn 2200 MS) system using dual-columns and dual-detectors to simultaneously analyze both low- and high-boiling point non-methane hydrocarbons (NMHCs). This system is an upgrade of the one as described by Chang et al. (2003). A built-in cryo-trap packed with fine glass beads was cooled with liquid nitrogen to $-170^{\circ} \mathrm{C}$. Air sample was drawn from the sample inlet through the cryo-trap at a rate of $12 \mathrm{~mL} \mathrm{~min}^{-1}$ for $20 \mathrm{~min}$, which gave an aliquot of $240 \mathrm{~mL}$ air sample. Desorption was made by flash heating the trap to $85^{\circ} \mathrm{C}$, and a stream of ultra-high purity helium (99.9999\%) was used to flush the trapped hydrocarbons to the columns. A glass Y-splitter was used to divide the flow into two streams for the following two columns, i.e. a PLOT column (Chrompack; $30 \mathrm{~m} \times 0.32 \mathrm{~mm}$; $\mathrm{df}=5.0 \mu \mathrm{m})$ connected to FID for separation and detection of C2-C4 compounds, and a DB-1 column (J\&W; 
Table 1. The NMHCs measured in this study.

\begin{tabular}{lll}
\hline 1,2,3-trimethylbenzene* & benzene* & n-butane* \\
\hline 1,2,4-trimethylbenzene* & beta-pinene & n-decane* \\
1,3,5-trimethylbenzene* & cis-2-butene* & n-heptane* \\
1-butene* & cis-2-hexene & n-hexane* \\
1-pentene* & cis-2-pentene* & n-nonane* \\
2,2,4-trimethylpentane* & cyclohexane* & n-octane* \\
2,2-dimthylbutane* & cyclopentane* & n-pentane* \\
2,3,4-trimethylpentane & cyclopentene & n-propylbenzene* \\
2,3-dimethylbutane & ethane & n-undecane* \\
2,3-dimethylpentane* & ethene & o-diethylbenzene \\
2,4-dimethylpentane* & ethylbenzene* & o-ethyltoluene* \\
2-methyl-1-pentene & ethyne & o-xylene* \\
2-methyl-2-butene & isobutane* & p-diethylbenzene* \\
2-methylheptane* & isobutene & p-ethyltoluene* \\
2-methylhexane* & isopentane* & propane* \\
2-methylpentane* & isoprene* & propene* \\
3-methyl-1-butene & isopropylbenzene* & styrene* \\
3-methylheptane* & m,p-xylene* & toluene* \\
3-methylhexane* & m-diethylbenzene* & trans-2-butene* \\
3-methylpentane* & methylcyclohexane* & trans-2-hexene \\
4-methyl-1-pentene & methylcyclopentane* & trans-2-pentene* \\
alpha-pinene & m-ethyltoluene* & \\
\hline & &
\end{tabular}

* Species measured in the CAREBeijing-2006.

$60 \mathrm{~m} \times 0.32 \mathrm{~mm} ; d f=1.0 \mu \mathrm{m})$ connected to MS for the separation and detection of $\mathrm{C} 5-\mathrm{C} 11$ compounds. The GC oven starts at $-15^{\circ} \mathrm{C}$ for $1.5 \mathrm{~min}$, ramps to $0^{\circ} \mathrm{C}$ at $10^{\circ} \mathrm{Cmin}^{-1}$, to $140^{\circ} \mathrm{C}$ at $5^{\circ} \mathrm{C} \mathrm{min}^{-1}$, to $180^{\circ} \mathrm{C}$ at $20^{\circ} \mathrm{C} \mathrm{min}^{-1}$, and ends at $180^{\circ} \mathrm{C}$ for $9.5 \mathrm{~min}$.

In addition to the $\mathrm{NO} / \mathrm{NO}_{2} / \mathrm{NO}_{\mathrm{y}}$ and $\mathrm{NMHCs}$ instruments for this intensive experiment, the PKU observatory was equipped with a general air quality station. All the instruments were calibrated regularly at the mid-night of each day during the campaign. The data of $\mathrm{CO}$ and $\mathrm{O}_{3}$ from the station will be included in the following analysis and discussion. Besides, the total short-wave irradiance, SWI, $(0.3-3.0 \mu \mathrm{m})$ was measured using an Eppley precision spectral pyranometers (PSP). The PSP sampled data per second and were subsequently averaged to 1 -min resolution.

\section{Results and discussion}

\subsection{Overview of the time series}

Figure 1 illustrates the time series of the hourly averaged mixing ratios of the respective species $\left(\mathrm{NO}, \mathrm{NO}_{2}, \mathrm{NO}_{\mathrm{y}}, \mathrm{NO}_{\mathrm{z}}\right.$, $\mathrm{O}_{3}, \mathrm{O}_{\mathrm{x}}, \mathrm{CO}$, and NMHCs) measured at the PKU station during August 2008. Here $\mathrm{NO}_{\mathrm{z}}$ is defined as the differences between $\mathrm{NO}_{\mathrm{y}}$ and $\mathrm{NO}_{\mathrm{x}}\left(\mathrm{NO}_{y}-\mathrm{NO}_{\mathrm{x}}\right)$, which are the oxidation products of $\mathrm{NO}_{\mathrm{x}}$. Note that the "total oxidant" $\left(\mathrm{O}_{\mathrm{x}}\right)$ is defined following Levy et al. (1985),

$$
\begin{aligned}
& \mathrm{O}_{\mathrm{x}}=\mathrm{O}_{3}+\mathrm{O}\left({ }^{3} \mathrm{P}\right)+\mathrm{O}\left({ }^{1} \mathrm{D}\right)+0.5 \cdot \mathrm{OH}+0.5 \cdot \mathrm{HO}_{2}+\mathrm{H}_{2} \mathrm{O}_{2} \\
& +\mathrm{NO}_{2}+2 \cdot \mathrm{NO}_{3}+3 \cdot \mathrm{N}_{2} \mathrm{O}_{5}+1.5 \cdot \mathrm{HNO}_{3} .
\end{aligned}
$$

Given that the mixing ratios of radicals, oxygen atoms, $\mathrm{H}_{2} \mathrm{O}_{2}$ and $\mathrm{N}_{2} \mathrm{O}_{5}$ are rather low in the atmosphere, the right hand side of Eq. (1) is dominated by $\mathrm{O}_{3}, \mathrm{NO}_{2}$, and $\mathrm{HNO}_{3}$. Further, because $\mathrm{HNO}_{3}$ is usually the predominant component of $\mathrm{NO}_{\mathrm{z}}$ in an urban area, the mixing ratio of $\mathrm{O}_{\mathrm{x}}$ was estimated by $\left[\mathrm{O}_{3}+\mathrm{NO}_{2}+1.5 \cdot \mathrm{NO}_{z}\right]$ in this study.

In the first week of August 2008, just before the Olympic Games, Beijing experienced an episode of high $\mathrm{O}_{3} / \mathrm{O}_{\mathrm{x}}$. The hourly $\left[\mathrm{O}_{3}\right]$ and $\left[\mathrm{O}_{\mathrm{x}}\right]$ reached their respective maxima, 135 and 169 ppbv, at 12:00 (local time $=\mathrm{GMT}+08: 00$ ) on $3 \mathrm{Au}-$ gust. The maximal levels of $\mathrm{NO}_{\mathrm{x}}, \mathrm{NO}_{\mathrm{y}}$, and $\mathrm{NMHCs}$ were observed at 11:00, i.e. $1 \mathrm{~h}$ prior to the peaks of $\mathrm{O}_{3}$ and $\mathrm{O}_{\mathrm{x}}$. Note that there was another $\mathrm{O}_{3} / \mathrm{O}_{\mathrm{x}}$ peak occurred at 17:00 on 3 August, implying the coupling influences of transport and in-situ photochemical production of ozone. This case will be analyzed and discussed in more details later on. The mixing ratio of $\mathrm{O}_{3}$ declined gradually since 6 August and remained below $100 \mathrm{ppbv}$, in spite of the daily $\mathrm{NO}_{\mathrm{x}} / \mathrm{NO}_{\mathrm{y}}$ spikes, during the Olympic Games. Apparently, the emission of $\mathrm{NO}_{\mathrm{x}}$ did not contribute efficiently to the formation of $\mathrm{O}_{3}$ in Beijing during the Olympics. The reduced photochemical activity was also indicated by the absence of $\mathrm{NO}_{z}$ peaks, as shown in the $\mathrm{NO}_{z}$ time series. The mitigation of $\mathrm{O}_{3} / \mathrm{O}_{\mathrm{x}}$ during the Beijing Olympic Games has been attributed to the weather conditions and/or the reduction in the emissions of precursors (Wang, et al., 2009b, 2010b). However, it was revealed from the time series that the production of $\mathrm{O}_{3}$ was not enhanced significantly on some days (e.g., 15-16 August) with strong solar flux. Thus the mechanisms for the observed reduction in $\mathrm{O}_{\mathrm{x}}$ need to be studied furthermore.

\subsection{Effectiveness of the emission control measures}

To examine the effectiveness of the emission control measures upon the air quality in Beijing, the ambient levels of nitrogen oxides, $\mathrm{O}_{3}, \mathrm{O}_{\mathrm{x}}$, NMHCs, and $\mathrm{CO}$ measured in this study were compared with the measurements made during the CAREBeijing-2006 campaign, i.e. 12 August - 9 September, 2006 (Chou et al., 2009). Table 2 tabulates the averages of the measurements for August 2008 and CAREBeijing-2006, respectively, and the differences are interpreted as the effectiveness of the emission control measures. In general, according to the observations, the reduction in the levels of primary pollutants was very significant; $\mathrm{NO}_{\mathrm{x}}, \mathrm{NO}_{\mathrm{y}}, \mathrm{NMHCs}$, and $\mathrm{CO}$ mixing ratios were reduced by $42.2,56.5,49.7$, and $27.8 \%$, respectively. This is consistent with the results of previous modeling as well as observation studies (e.g., Wang et al., 2009a, 2010a, b, c). Averaged meteorological parameters (wind speed, T, RH) for 2006 and 2008 campaigns are also listed in Table 2 . The ambient temperature and humidity in August 2008 are slightly higher 

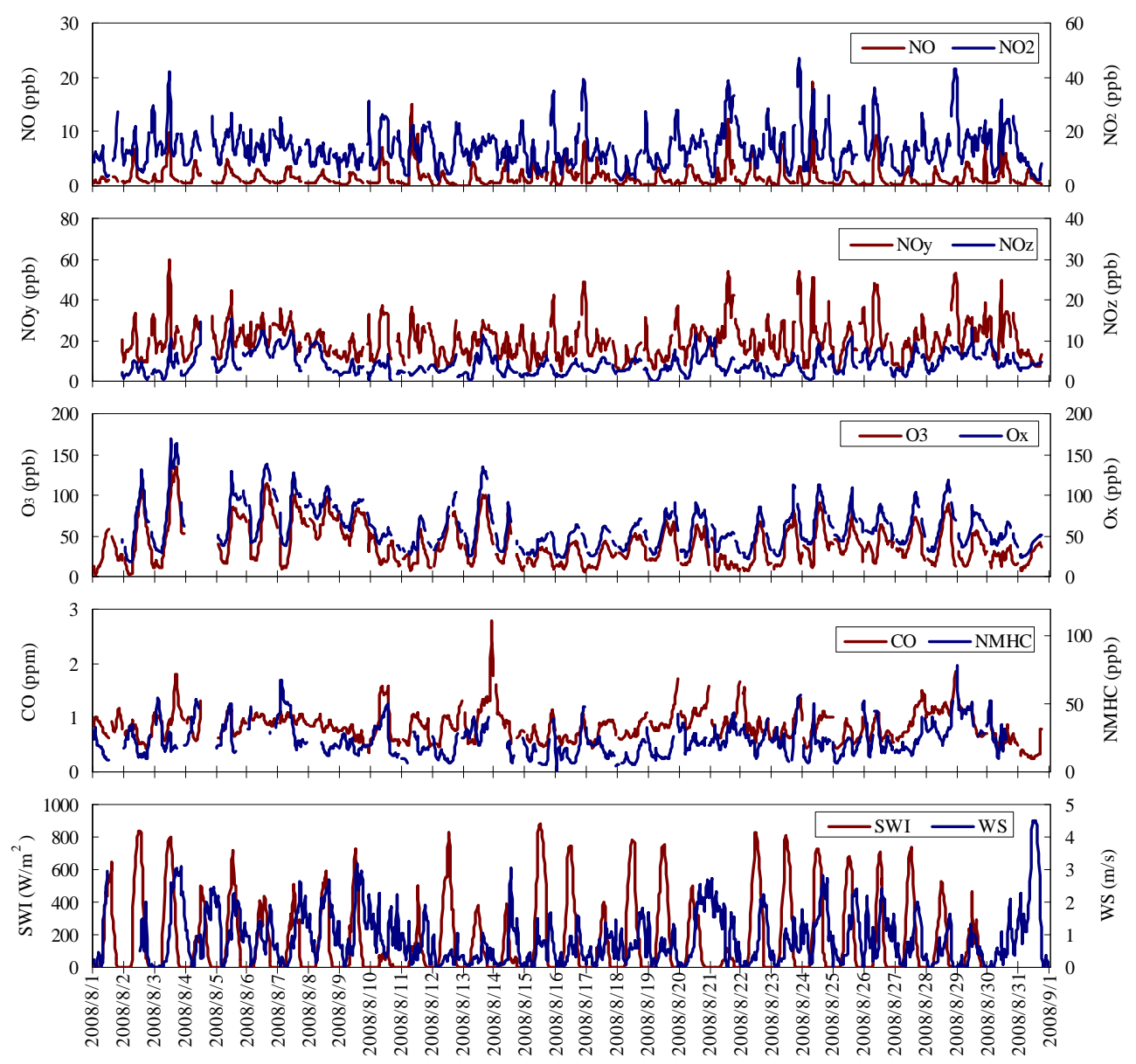

Fig. 1. Time series of the hourly averaged concentrations of the trace gases, wind speed, and short wave irradiance measured at the PKU station during August 2008.

than during the CAREBeijing-2006 campaign, whereas the averaged wind speed decreased by $\sim 30 \%$. Obviously, the reduction in the mixing ratios of air pollutants can not be explained by the changes in the meteorological conditions. This is in agreement with the results of Wang et al. (2009b).

In contrast to the primary pollutants, the averaged level of $\mathrm{O}_{3}$ increased from $28.2 \pm 27.2 \mathrm{ppbv}$ to $40.1 \pm 25.1 \mathrm{ppbv}$, or by $42 \%$. Meanwhile, the sum of $\mathrm{O}_{3}$ and $\mathrm{NO}_{2}$ mixing ratios increased from $48.2 \pm 24.5 \mathrm{ppbv}$ to $53.9 \pm 25.0 \mathrm{ppbv}(11.8 \%)$, which means reduced titration effect between $\mathrm{O}_{3}$ and $\mathrm{NO}$ for the reduction in $\mathrm{NO}_{\mathrm{x}}$ emission can explain only partly the increases in ambient $\mathrm{O}_{3}$. It is underlined that the averaged level of $\mathrm{O}_{\mathrm{x}}$ decreased from $76.6 \pm 28.7 \mathrm{ppbv}$ to $60.3 \pm 26.9 \mathrm{ppbv}$, which is equivalent to a reduction of $21 \%$. Among the components of $\mathrm{O}_{\mathrm{x}}$, the mixing ratios of $\mathrm{NO}_{\mathrm{z}}$ decreased most significantly. The campaign average of $\mathrm{NO}_{z}$ mixing ratio decreased from $19.0 \pm 6.3 \mathrm{ppbv}$ to $4.3 \pm 2.7 \mathrm{ppbv}$, i.e. $77.4 \%$. The major cause of the drastic decreases in $\mathrm{NO}_{\mathrm{z}}$ is most likely the reduction in $\mathrm{NO}_{\mathrm{x}}$ emissions. Nevertheless, it could also be a result of enhanced wet deposition in the August 2008. It is worth noting that the present study is the first re- port showing the consistency between the levels of $\mathrm{O}_{\mathrm{x}}$ and its precursors and indicating the changes in the composition of oxidant in Beijing during the 2008 Olympics.

In addition to the general assessment, the diurnal variations of the mixing ratios of trace gases could provide further insight, in particular the implications for photochemistry. Figure 2a-d depict the averaged diurnal patterns of $\mathrm{NO}, \mathrm{NO}_{2}, \mathrm{NO}_{\mathrm{z}}$ and $\mathrm{NO}_{\mathrm{y}}$, respectively, for the CAREBeijing2006 and CAREBeijing-2008. The most striking features are that the reduction in $\mathrm{NO}$ and $\mathrm{NO}_{2}$ occurred in the morning and evening but not as significantly during the midday, whereas the reduction in $\mathrm{NO}_{z}$ persisted throughout the whole day. Chou et al. (2009) indicated efficient conversion of freshly emitted $\mathrm{NO}_{\mathrm{x}}$ to $\mathrm{NO}_{\mathrm{z}}$ in the morning during CAREBeijing-2006. The results of this study further suggest that the diminution of the morning rush-hour emissions of $\mathrm{NO}_{\mathrm{x}}$ can contribute most effectively to the reduction of $\mathrm{NO}_{\mathrm{z}}$. However, the persisted levels of $\mathrm{NO}$ and $\mathrm{NO}_{2}$ during midday were not agreeing with the emission control measures. Figure $2 \mathrm{e}-\mathrm{f}$ display the diurnal variations of the other two major primary pollutants, $\mathrm{CO}$ and NMHCs. In contrast to $\mathrm{NO}_{\mathrm{x}}$, the 

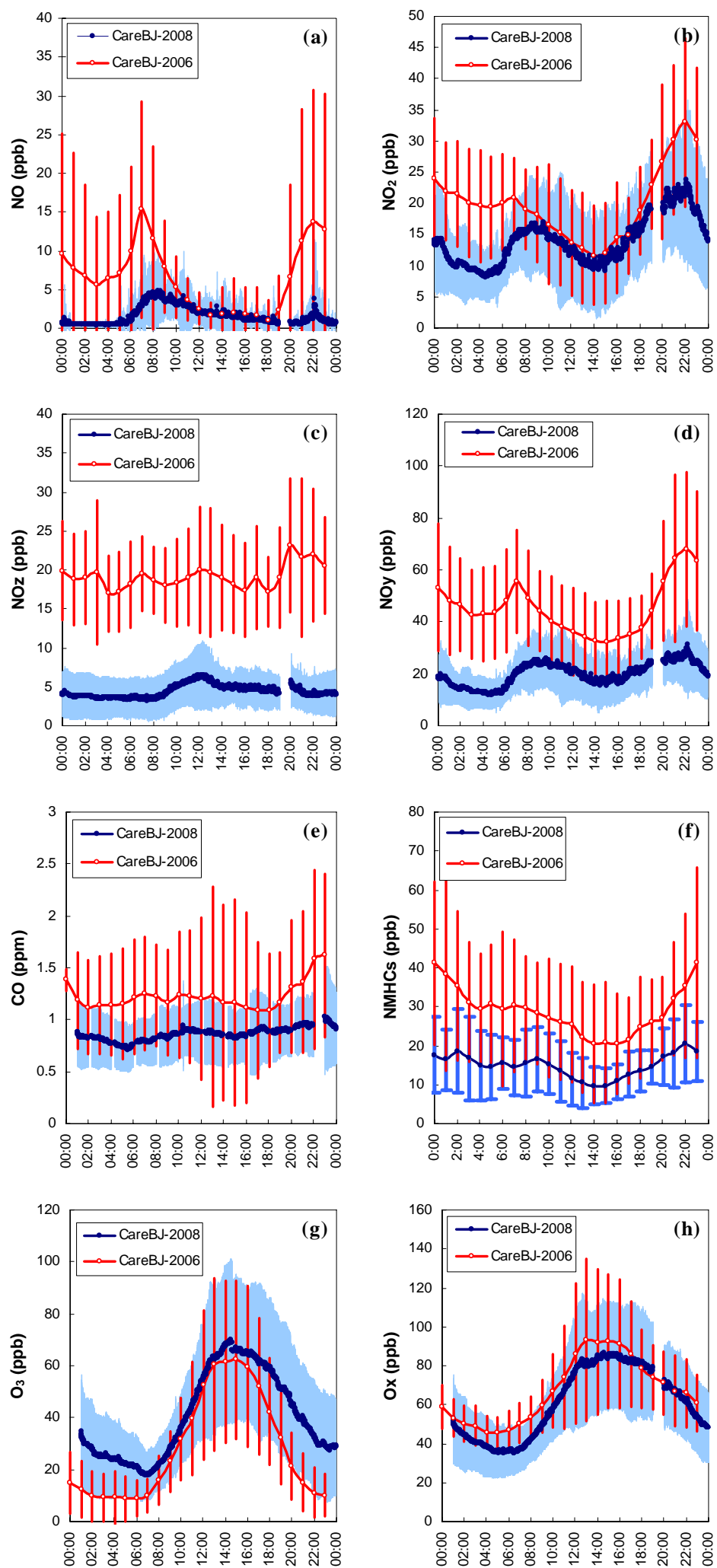

Fig. 2. Averaged diurnal variations in the mixing ratios of trace gases measured at the PKU observatory during the CAREBeijing-2006 and CAREBeijing-2008, respectively. The time resolution of the measurements, except NMHCs, of the 2008 campaign is 1 min, whereas the results of the 2006 campaign are hourly based. The ranges of $\pm 1 \sigma$ are indicated by the error bars associated with the hourly means or shaded for the 1-min. data. (a) $\mathrm{NO}$; (b) $\mathrm{NO}_{2}$; (c) $\mathrm{NO}_{\mathrm{z}}$; (d) $\mathrm{NO}_{\mathrm{y}}$; (e) $\mathrm{CO}$; (f) $\mathrm{NMHCs}$; (g) $\mathrm{O}_{3}$; (h) $\mathrm{O}_{\mathrm{x}}$. 
Table 2. Statistics of the ambient levels of trace gases and meteorological parameters measured in Beijing during CAREBeijing-2006 and CAREBeijing-2008. The standard deviation of each mean value is noted in the parentheses.

\begin{tabular}{lccr}
\hline & $\begin{array}{c}\text { CareBeijing-2006 } \\
(12 \text { Aug-9 Sep 2006) }\end{array}$ & $\begin{array}{c}\text { CareBeijing-2008 } \\
(1-31 \text { Aug 2008) }\end{array}$ & $\begin{array}{r}\text { Reduction } \\
(\%)\end{array}$ \\
\hline $\mathrm{NO}(\mathrm{ppb})$ & $6.9(11.3)$ & $1.6(1.9)$ & 76.8 \\
$\mathrm{NO}_{2}(\mathrm{ppb})$ & $19.5(10.2)$ & $13.7(7.2)$ & 29.7 \\
$\mathrm{NO}_{\mathrm{x}}(\mathrm{ppb})$ & $26.3(17.5)$ & $15.2(8.2)$ & 42.2 \\
$\mathrm{NO}_{\mathrm{y}}(\mathrm{ppb})$ & $45.3(21.5)$ & $19.7(9.0)$ & 56.5 \\
$\mathrm{NO}_{\mathrm{z}}(\mathrm{ppb})$ & $19.0(6.3)$ & $4.3(2.7)$ & 77.4 \\
$\mathrm{NMHC}^{*}(\mathrm{ppb})$ & $29.0(17.0)$ & $14.6(8.0) / 23.3(11.9)$ & 49.7 \\
$\mathrm{CO}(\mathrm{ppb})$ & $1173(623)$ & $847(275)$ & 27.8 \\
$\mathrm{O}_{3}(\mathrm{ppb})$ & $28.2(27.2)$ & $40.1(25.1)$ & -42.2 \\
$\mathrm{O}_{3}+\mathrm{NO}{ }_{2}(\mathrm{ppb})$ & $48.2(24.5)$ & $53.9(25.0)$ & -11.8 \\
$\mathrm{O}_{\mathrm{x}}(\mathrm{ppb})$ & $76.6(28.7)$ & $60.3(26.9)$ & 21.3 \\
$\mathrm{O}_{3}$ max $(\mathrm{ppb})^{* *}$ & $69.9(33.9)$ & $73.3(25.3)$ & -4.9 \\
$\mathrm{O}_{\mathrm{x} \_m a x}(\mathrm{ppb})^{* *}$ & $120.8(42.3)$ & $96.5(29.1)$ & 20.1 \\
$\mathrm{Temp}\left({ }^{\circ} \mathrm{C}\right)$ & $25.8(4.8)$ & $27.4(4.1)$ & -6.2 \\
$\mathrm{RH}^{*}(\%)$ & $64.3(19.9)$ & $68.8(17.2)$ & -7.0 \\
Wind Speed $\left(\mathrm{m} \mathrm{s}^{-1}\right)$ & $1.4(1.3)$ & $0.9(0.8)$ & 35.7 \\
\hline
\end{tabular}

\footnotetext{
* The NMHCs measurements of CAREBeijing-2008 include 65 species as listed in Table 1; among which 49 species were measured in CareBeijing-2006. The reduction ratio is based on the measurements of 49 species.

** $\mathrm{O}_{3 \_ \text {max }}$ and $\mathrm{O}_{\mathrm{x} \_ \text {max }}$ denote the daily peak levels of $\mathrm{O}_{3}$ and $\mathrm{O}_{\mathrm{x}}$, respectively.
}

mitigation of air pollution was quite evident in the figures. Indeed, the reduction in traffics and relevant pollutants' emissions has been validated by on-road measurements (Wang et al., 2009a). Thus the persisted levels of $\mathrm{NO}$ and $\mathrm{NO}_{2}$ during midday is inferred to be a result of photochemical dynamics. This inference will be examined in the following case studies. Figure $2 \mathrm{~g}-\mathrm{h}$ depict the diurnal patterns for $\mathrm{O}_{3}$ and $\mathrm{O}_{\mathrm{x}}$, respectively. The mixing ratio of $\mathrm{O}_{3}$ was higher during the 2008 campaign, whereas $\mathrm{O}_{\mathrm{x}}$ was higher in 2006 . The differences in $\mathrm{O}_{3}$ were much larger in nighttime than in daytime, indicating the changes in the $\mathrm{NO}-\mathrm{O}_{3}$ titration due to emission reduction. The mixing ratio and the increasing rate of $\mathrm{O}_{3}$ from morning to noontime are comparable in the two campaigns; meanwhile the $\mathrm{O}_{\mathrm{x}}$ of 2008 campaign kept slightly lower than in the 2006 campaign. Note that the mixing ratio of $\mathrm{O}_{3}$ kept increasing in the early afternoon of 2008 and resulted in significantly higher daily maximum than in 2006, disagreeing with the behavior of $\mathrm{O}_{\mathrm{x}}$. In terms of monthly average, the daily peak level of 1-h $\mathrm{O}_{3}\left(\mathrm{O}_{3 \_ \text {max }}\right)$ in August 2008 increased by $4.9 \%$ than during the 2006 campaign, whereas the $\mathrm{O}_{\mathrm{x} \_ \text {max }}$ (daily peak level of 1-h $\mathrm{O}_{\mathrm{x}}$ ) was reduced by $20.1 \%$ (shown in Table 2). The inconsistency between $\mathrm{O}_{3}$ and $\mathrm{O}_{x}$ implies that the increasing $\mathrm{O}_{3}$ in early afternoon was not caused by enhancement in $\mathrm{O}_{3}$ production, and was more likely a result of changes in the partition among the components of $\mathrm{O}_{\mathrm{x}}$.

\subsection{Ozone production efficiency of $\mathrm{NO}_{\mathrm{x}}$ : case studies}

Despite of the prolonged rainy events in Beijing during August 2008, there were still some days of clear skies inbetween the rains (as shown in Fig. 1) that allow in-depth analysis upon the photochemical reactions. Ozone production efficiency of $\mathrm{NO}_{\mathrm{x}}$ (OPEx) is among the key parameters of $\mathrm{NO}_{\mathrm{x}}-\mathrm{O}_{3}$ chemistry, which is defined as the number of ozone molecules produced by one $\mathrm{NO}_{\mathrm{x}}$ molecule in the $\mathrm{NO}_{\mathrm{x}}-$ catalyzed photochemical reactions (Liu et al., 1987). In the followings, two distinct cases will be presented in the context of $\mathrm{OPE}_{\mathrm{x}}$. The case of 3 August is a high $\mathrm{O}_{3}$ episode, whereas the $\mathrm{O}_{3}$ mixing ratio was leveling off at $30-40 \mathrm{ppbv}$ in the daytime of 15 August.

\subsubsection{Case 1: 3 August 2008}

Figure 3a-e illustrate the mixing ratios of trace gases and the meteorological parameters measured at the PKU observatory on 3 August 2008. As indicated by the solar flux, it was a rather clear day. Advection of air mass was inhibited until the nocturnal boundary layer got broken in the morning and, then, southerly flows were prevailing throughout the day. The common $\mathrm{NO}_{\mathrm{x}} / \mathrm{NO}_{\mathrm{y}}$ peaks for morning rush hours in an urban area were diminished significantly, as comparing with the measurements of CAREBeijing-2006 (Chou et al., 2009). Nevertheless, the freshly emitted NO was still noticeable. The mixing ratios of $\mathrm{O}_{3}, \mathrm{O}_{\mathrm{x}}$, and $\mathrm{NO}_{\mathrm{z}}$ increased drastically from $\sim$ 09:00 to $\sim 12: 00$. Note the spikes of $\mathrm{NO} / \mathrm{NO}_{2} / \mathrm{NO}_{\mathrm{y}}$ peaking at $\sim 11: 00$, which resulted in the titration dip in $\mathrm{O}_{3}$. 

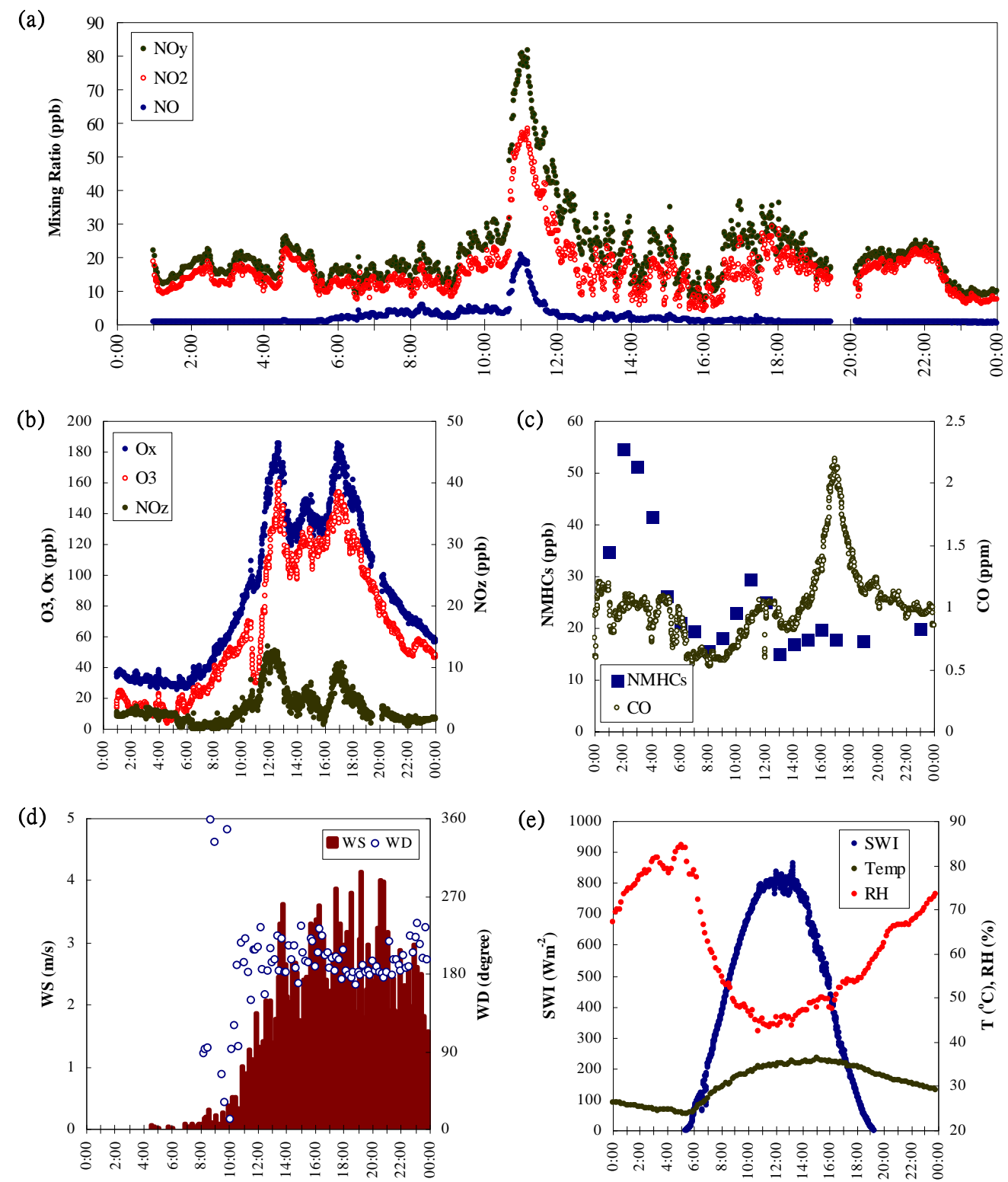

Fig. 3. Time series of the mixing ratios of trace gases and the meteorological conditions in Beijing for 3 August 2008. (a) $\mathrm{NO} \mathrm{NO}_{2}$, and $\mathrm{NO}_{\mathrm{y}}$; (b) $\mathrm{O}_{\mathrm{x}}, \mathrm{O}_{3}$, and $\mathrm{NO}_{\mathrm{z}}$; (c) $\mathrm{NMHCs}$ and $\mathrm{CO}$; (d) wind speed and direction; (e) ambient temperature, RH, and SWI.

The causes of the event are not clear yet, but most likely due to some local activities. Figure 4 analyzes the data in terms of ozone production efficiency of $\mathrm{NO}_{\mathrm{x}}\left(\mathrm{OPE}_{\mathrm{x}}\right)$ to examine the perturbation of the $\mathrm{NO}_{\mathrm{x}}$ spike upon the $\mathrm{O}_{3}$ production. Note that the derivation of $\mathrm{OPE}_{\mathrm{x}}$ was following the regression method suggested by Trainer et al. (1993); however, instead of analyzing the correlation of $\mathrm{O}_{3}$ and $\mathrm{NO}_{\mathrm{z}}$, here the $\mathrm{OPE}_{\mathrm{x}}$ was derived from the slope of $\left[\mathrm{O}_{\mathrm{x}}\right]$ vs. $\left[\mathrm{NO}_{\mathrm{z}}\right]$. It was revealed that the $\mathrm{OPE}_{\mathrm{x}}$ decreased from 8.6 before the $\mathrm{NO}_{\mathrm{x}}$ spike to 3.6 during the episode and, in turn, bound up to 7.9 mole mole ${ }^{-1}$ after the event. Obviously, the $\mathrm{NO}_{\mathrm{x}}$ injected into the atmosphere was converted to $\mathrm{NO}_{z}$ efficiently dur- ing the episode. The enhanced $\mathrm{NO}_{\mathrm{x}}-\mathrm{NO}_{\mathrm{z}}$ conversion should have increased the consumption of radicals and, thereby, retarded the ozone production. Figure 5 shows that the 1-min mixing ratios of $\mathrm{O}_{3}(10: 30-12: 30)$ correlate linearly with the corresponding ratios of $\mathrm{NO}_{2}$ to $\mathrm{NO}$, being consistent with the photo-stationary state relation. This consistency allows approximation of the ozone production rate $\left(\mathrm{P}_{\mathrm{O}_{3}}\right)$ following the photo-stationary state equation (Frost et al, 1998),

$$
P_{\mathrm{O}_{3}}=j_{\mathrm{NO}_{2}} \cdot\left[\mathrm{NO}_{2}\right]-k_{\mathrm{NO}-\mathrm{O}_{3}} \cdot\left[\mathrm{O}_{3}\right] \cdot[\mathrm{NO}]
$$

Without direct measurement of the photolysis rates of $\mathrm{NO}_{2}, \quad j_{\mathrm{NO}_{2}}$, the values of $j_{\mathrm{NO}_{2}}$ were estimated being 


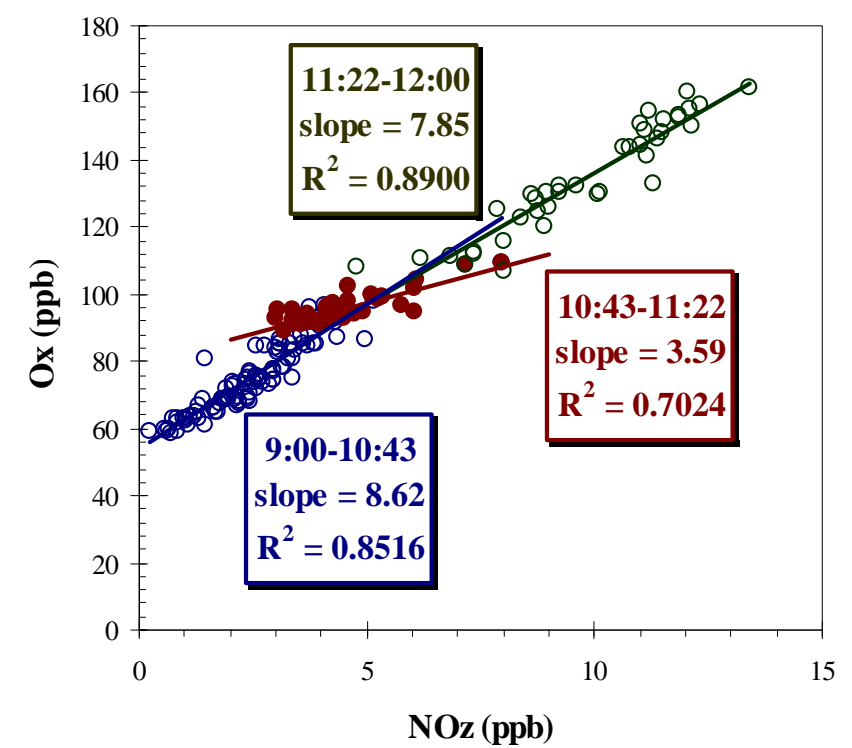

Fig. 4. Correlation between $\mathrm{O}_{\mathrm{x}}$ and $\mathrm{NO}_{\mathrm{z}}$ observed at the $\mathrm{PKU}$ observatory in the morning of 3 August 2008. The data are divided into three periods to characterize the ozone production efficiency of $\mathrm{NO}_{\mathrm{x}}(\mathrm{OPEx})$ before, during, and after the spiky event of primary pollutants, respectively.

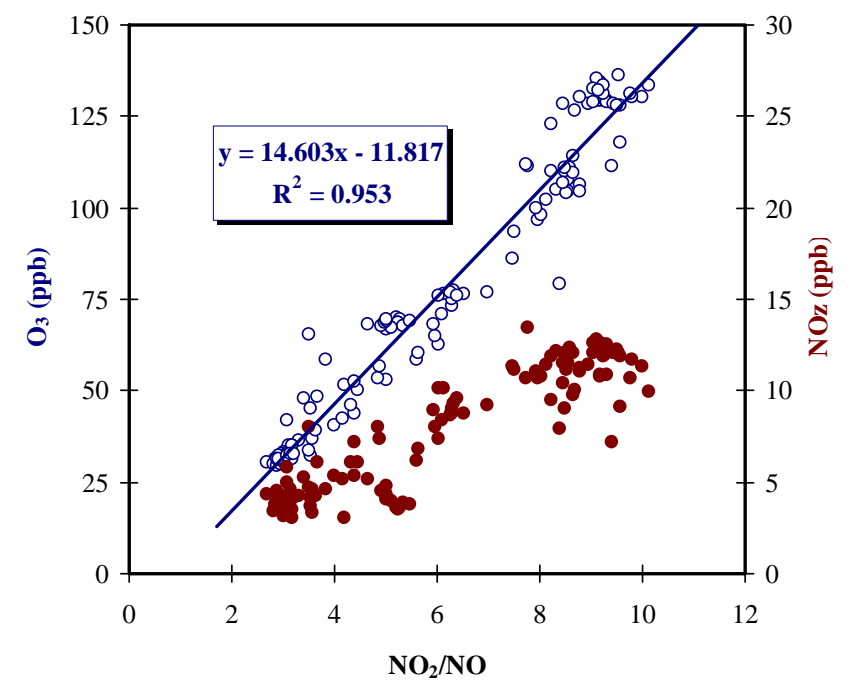

Fig. 5. Correlation of $\mathrm{O}_{3}$ and $\mathrm{NO}_{\mathrm{z}}$, respectively, versus the $\mathrm{NO}_{2} / \mathrm{NO}$ ratio for the period of 10:30-12:30, 3 August 2008. The linear regression is associated to the $\mathrm{O}_{3}$ data. The increasing trend of $\mathrm{NO}_{\mathrm{Z}}$ with the $\mathrm{NO}_{2} / \mathrm{NO}$ ratio is discontinued as $\mathrm{NO}_{2} / \mathrm{NO}>8$.

$0.008 \mathrm{~s}^{-1}$ for noontime $(11: 30-12: 30)$ and $0.007 \mathrm{~s}^{-1}$ for late morning (10:30-11:30). The rate constant $k_{\mathrm{NO}-\mathrm{O}_{3}}$ was calculated following Demore et al. (1997),

$k_{\mathrm{O}_{3}-\mathrm{NO}}=2.0 \times 10^{-12} \exp \left(\frac{-1400}{T}\right)$ (a) NOAA HYSPLIT MODEL Backward trajectory ending at 0900 UTC 03 Aug 08 GDAS Meteorological Data

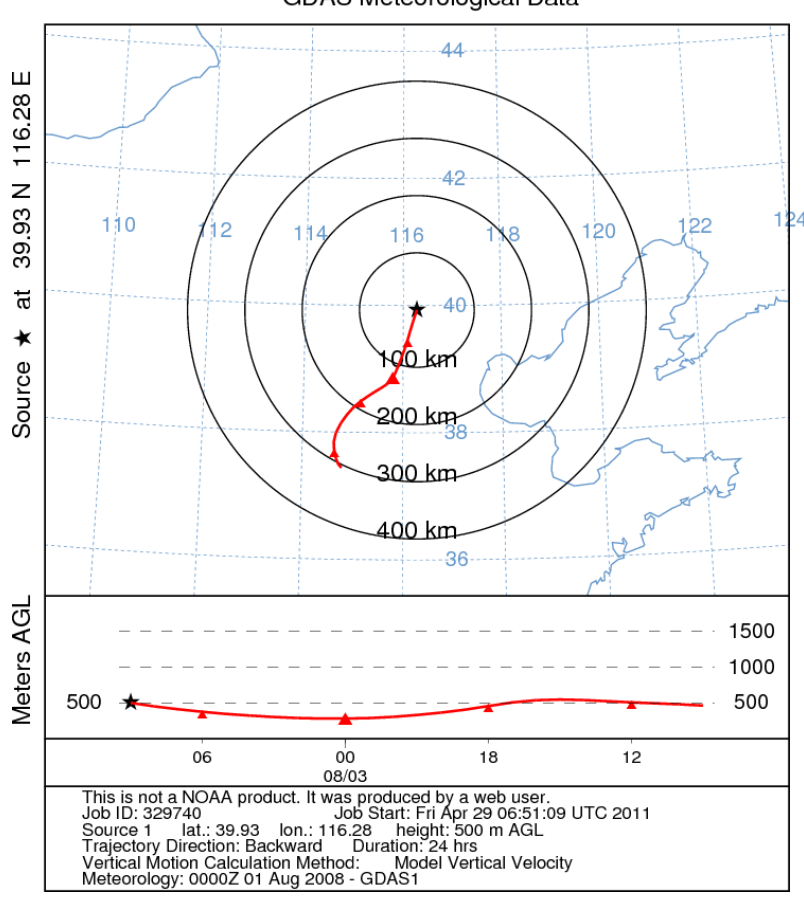

(b)

NOAA HYSPLIT MODEL Backward trajectory ending at 0400 UTC 15 Aug 08 GDAS Meteorological Data

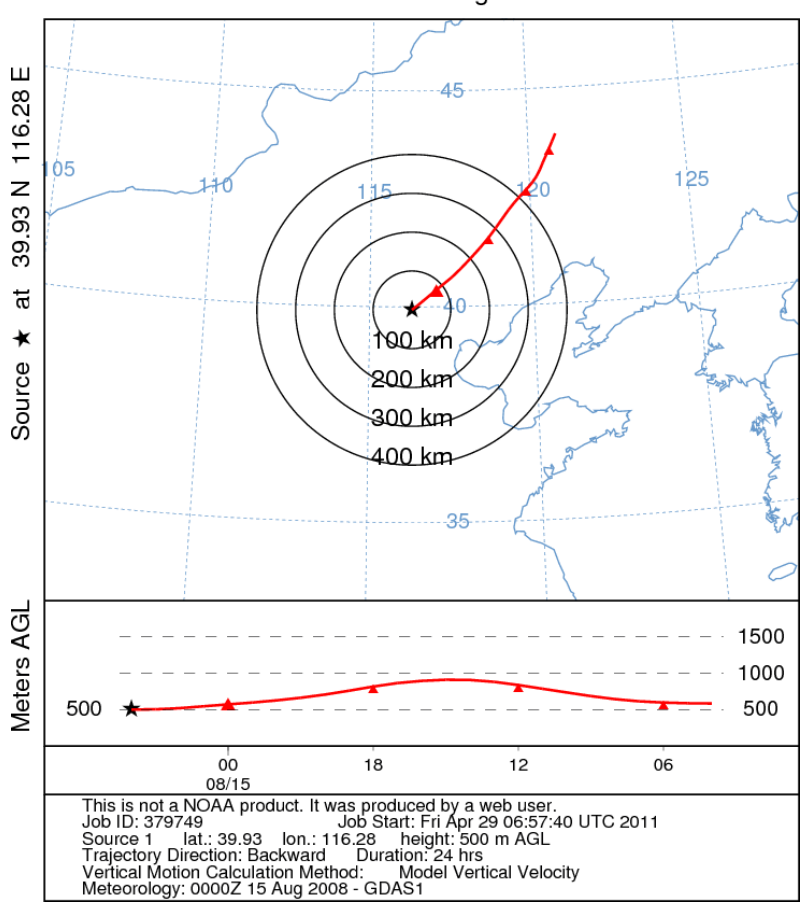

Fig. 6. Backward trajectories of air mass arriving Beijing at 17:00, 3 August (a), and at 12:00, 15 August 2008 (b). The trajectories were calculated for $24 \mathrm{~h}$ from an altitude of $500 \mathrm{~m}$ above the ground level of Beijing. 

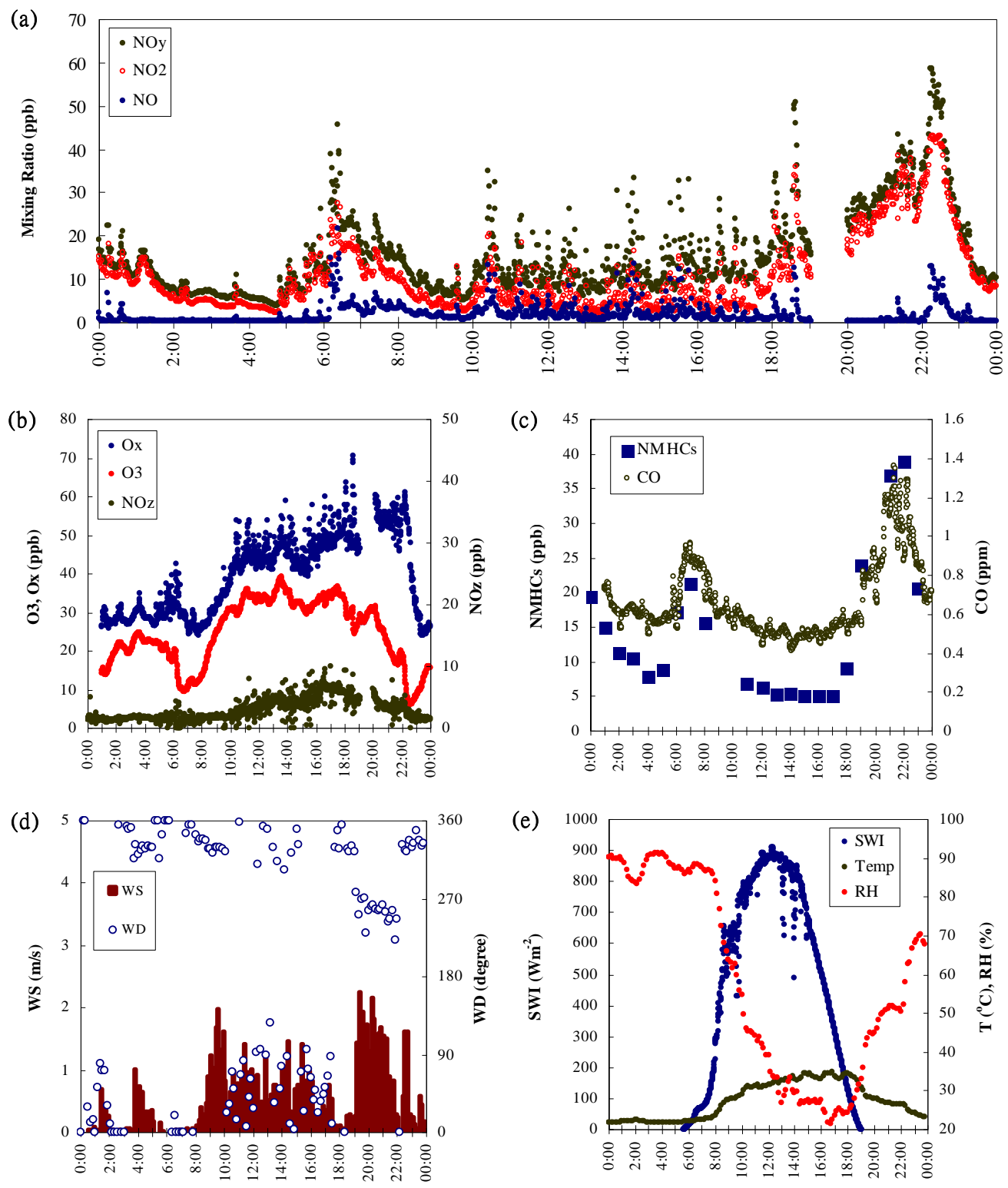

Fig. 7. Same as Fig. 3 but for 15 August 2008.

The calculation indicated that the 5-min averaged $\mathrm{P}_{\mathrm{O}_{3}}$ was $30.7 \pm 9.2 \mathrm{ppbh}^{-1}$ for 10:31-10:35, and increased to $75.8 \pm 20.1 \mathrm{ppb} \mathrm{h}^{-1}$ at noon time (12:26-12:30). The values of $\mathrm{P}_{\mathrm{O}_{3}}$ are significantly higher than those observed in the US urban areas by a factor of 3-7 (Kleinman et al., 2002), and are comparable to recent observation in the Mexico City (Wood et al., 2009). Note that the range of $\mathrm{P}_{\mathrm{O}_{3}}$ is comparable to that observed in Beijing during the summer of 2006 (Lu et al., 2010). Such a high $\mathrm{P}_{\mathrm{O}_{3}}$ explains, at least partly, the high ozone levels observed in August 2008. The correlation between the $\mathrm{NO}_{z}$ concentration and the ratio of $\mathrm{NO}_{2}$ to $\mathrm{NO}$ is also shown in Fig. 5. Along with the photochemical evolution of the air mass, it was revealed that the ambient level of $\mathrm{NO}_{\mathrm{z}}$ increased with $\mathrm{NO}_{2} / \mathrm{NO}$ ratio until $\mathrm{NO}_{2} / \mathrm{NO}>8$, whereas the mixing ratio of $\mathrm{O}_{3}$ kept increasing. Consequently, the ratio of $\mathrm{O}_{3}$ to $\mathrm{NO}_{\mathrm{z}}$ increased to be above 10 , indicating that the $\mathrm{O}_{3}$ production shifted from VOC-sensitive regime to $\mathrm{NO}_{\mathrm{x}}$-sensitive regime (Sillman, 1995). Moreover, the leveling-off of $\mathrm{NO}_{\mathrm{z}}$ suggests that the consumption of $\mathrm{NO}_{\mathrm{x}}$ was getting limited. As a result, the fraction of $\mathrm{NO}_{\mathrm{x}}$ in $\mathrm{NO}_{\mathrm{y}}$ was significantly higher than that observed in CAREBeijing-2006 (Chou et al., 2009). Thus, in spite of the substantial reduction in $\mathrm{NO}_{\mathrm{x}}$ emissions in Beijing during the Olympic period, particularly during the morning rush hours, the ambient levels of $\mathrm{NO}$ and $\mathrm{NO}_{2}$ were not reduced as well during the midday. 


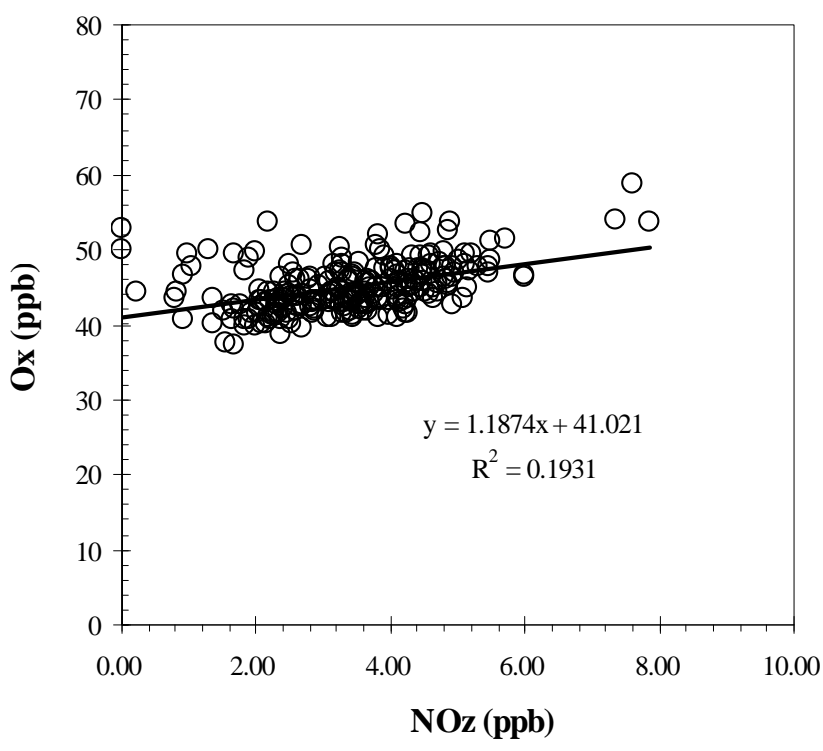

Fig. 8. Correlation between $\mathrm{O}_{\mathrm{x}}$ and $\mathrm{NO}_{\mathrm{z}}$ observed at the PKU observatory during the midday (10:00-14:00) of 15 August 2008. An averaged OPEx of 1.2 mole mole ${ }^{-1}$ is derived from the linear regression model.

As shown in Fig. 3b, there was a second $\mathrm{O}_{\mathrm{x}}$ peak occurred in the late afternoon of 3 August. As a result, the daily maximum 8-h mean of $\mathrm{O}_{3}$ reached $119.2 \mathrm{ppbv}$ for the period from 12:00-20:00 LST. The mixing ratios of $\mathrm{NO}_{\mathrm{y}}$ and $\mathrm{NO}_{\mathrm{z}}$ increased coincidently. Unlike the midday peak, this afternoon $\mathrm{O}_{\mathrm{x}}$ peak was associated with a strong $\mathrm{CO}$ peak but without significant changes in the NMHCs. The declined solar flux at that time excluded the possibility of strong in-situ photochemical production of $\mathrm{O}_{3}$. Thus, the most probable cause of the late afternoon episode is transport of aged air mass from surrounding urban areas, where the emissions of $\mathrm{CO}$ were not controlled as did in Beijing. Figure 6 illustrates the 24-h backward trajectory of the surface air mass arriving in Beijing at 17:00, which suggests that the photochemically-aged plume was associated with moderate southwesterly flows $(\sim 300 \mathrm{~km}$ per day). The influences of the southerly transported polluted air mass on the air quality in Beijing have been discussed in previous studies (e.g., An et al., 2007, Wang et al., 2010b). The point underlined in this case study is that the coupling of in-situ photochemical ozone production during midday and the transport of ozone plumes in the late afternoon could further impact the air quality, particularly in terms of the "8-h-mean" $\mathrm{O}_{3}$ guideline (WHO, 2006).

\subsubsection{Case 2: 15 August 2008}

Figures 7a-e show the measurements of trace gases and meteorological parameters on 15 August 2008. Note that the northerly winds were prevailing and, as a result, the transport of polluted air mass from the southern North China Plains to
Beijing was prevented. Despite of the rains in early morning, the skies were very clear during the daytime. However, in contrast to the previous case, the mixing ratio of $\mathrm{O}_{3}$ was kept at 30-40 ppbv during the daytime. The observed $\mathrm{O}_{3}$ leveling-off suggests that the production and loss rates of ozone were comparable to each other. The major sinks of $\mathrm{O}_{3}$ in the boundary layer include dry deposition and photolysis. With general conditions in urban areas, it was estimated that the maximum loss rate of $\mathrm{O}_{3}$ could be around $10 \mathrm{ppbh}^{-1}$ only (Wood et al., 2009, Lu et al., 2010). Given the strong solar flux, the photolysis rate of $\mathrm{NO}_{2}$ and production rate of $\mathrm{OH}$ on 15 August 2008 should be comparable to those on 3 August, respectively. Thus, there must be a major $\mathrm{OH} \operatorname{sink}(\mathrm{s})$ that inhibited the formation of $\mathrm{O}_{3}$ on 15 August.

On 15 August, the mixing ratio of $\mathrm{NO}_{\mathrm{z}}$ was increasing from $\sim 0$ to $\sim 10 \mathrm{ppbv}$ during the daytime (as shown in Fig. 7b), implying that a substantial amount of $\mathrm{OH}$ radicals was consumed by reacting with $\mathrm{NO}_{2}$. Figure 8 illustrates the correlation between $\mathrm{NO}_{z}$ and $\mathrm{O}_{\mathrm{x}}$ and gives an averaged OPEx of 1.2 mole mole $^{-1}$ for 10:00-14:00. Such a low OPEx suggests that the photochemical chain length of $\mathrm{NO}_{\mathrm{x}}$ was very short and $\mathrm{NO}_{\mathrm{x}}$ was the major terminator of radicals. Given that the reaction between $\mathrm{NO}_{2}$ and $\mathrm{OH}$ is the primary sink of $\mathrm{NO}_{\mathrm{x}}$ in the boundary layer, it was inferred from the low OPEx that the $\mathrm{O}_{3}$ production was retarded by the consumption of $\mathrm{OH}$ for $\mathrm{NO}_{2}$ oxidation. However, the high-end estimates of the consumption rates of $\mathrm{OH}$ due to reacting with $\mathrm{NO}_{2}$ were around $3 \mathrm{ppb} \mathrm{h}^{-1}$, which were calculated based on observed $\mathrm{NO}_{2}$ concentrations, using $k_{\mathrm{NO}_{2}-\mathrm{OH}}=9 \times 10^{-12} \mathrm{~cm}^{3} \mathrm{~s}^{-1}$ (Donahue et al., 1997) and assuming $[\mathrm{OH}]=1 \times 10^{7} \mathrm{~cm}^{-3}$. That is evidently not enough to explain the $\mathrm{O}_{3}$ leveling-off. Figure $7 \mathrm{c}$ shows that the mixing ratio of NMHCs was only 6.1 ppbv for the major photochemical time slot, i.e. 11:00-13:00, of 15 August. Comparing with $23.2 \mathrm{ppbv}$ on 3 August, the concentration of NMHCs was reduced by $74 \%$. Meanwhile, the total $\mathrm{OH}$-reactivity of $\mathrm{CO}$ and the measured NMHCs decreased from 9.3 to $4.8 \mathrm{~s}^{-1}$, or by $\sim 50 \%$. The reduction in OH-reactivity of NMHCs will certainly inhibit the production of organic peroxy radicals $\left(\mathrm{RO}_{2}\right)$. Considering the recycling of $\mathrm{OH}$ through the reactions of peroxy radicals and NO (Hofzumahaus et al., 2009), the effects of the reduction in the OH-reactivity of NMHCs upon the $\mathrm{O}_{3}$ production could have been amplified to a certain degree in this case.

\subsubsection{Implications of the case studies}

The two distinct cases discussed above demonstrate the responses of ozone production to the changes in the precursor levels, and provide important clues for further studies. In the first case ( 3 August), the ozone production was found being shifting from VOC-sensitive in late morning to $\mathrm{NO}_{\mathrm{x}}{ }^{-}$ sensitive regime in early afternoon. Thus, the ozone production was first fueled by the substantial emissions of VOCs and, then, that shift could have inhibited the consumption of 
$\mathrm{NO}_{\mathrm{x}}$ and allowed the further increases of the $\mathrm{O}_{3}$ mixing ratio in the early afternoon. Such a scenario could be responsible partly for the formation of high ozone episodes in Beijing, and should be considered and analyzed in more details in further modeling work. On the contrary, in case without the shift in the photochemical regime (i.e., 15 August), the photochemical production of $\mathrm{O}_{3}$ declined substantially for the reduced $\mathrm{OH}$-reactivity of VOCs during the midday. This could also explain the extremely low OPEx observed in Beijing on 15 August 2008.

\section{Conclusions}

During August 2008, including the period of the 29th Summer Olympic Games, an intensive atmospheric chemistry experiment was conducted at the air quality observatory of the Peking University in Beijing, China. The measurements were compared with the results of the CAREBeijing-2006, which was carried out in the summer of 2006, to infer the emission reduction in the Olympic month. Moreover, the measurements of the oxides of nitrogen were analyzed and discussed in details with implications for the photochemical ozone production in Beijing.

The monthly means of $\mathrm{NO}, \mathrm{NO}_{2}, \mathrm{NO}_{\mathrm{x}}, \mathrm{NO}_{\mathrm{y}}$, and $\mathrm{NO}_{\mathrm{z}}$ mixing ratios for August 2008 are $1.6 \pm 1.9,13.7 \pm 7.2$, $15.2 \pm 8.2,19.7 \pm 9.0$, and $4.3 \pm 2.7 \mathrm{ppbv}$, respectively. As comparing with the measurements made in the summer of 2006, the overall reductions in $\mathrm{NO}_{\mathrm{x}} / \mathrm{NO}_{\mathrm{y}}$ are $42.2 / 56.5 \%$. Besides, the observations showed that the ambient levels of $\mathrm{CO}$ and NMHCs reduced by $27.8 \%$ and $49.7 \%$, respectively, agreeing with the reduction in $\mathrm{NO}_{\mathrm{x}}$ and $\mathrm{NO}_{\mathrm{y}}$. Thus, in line with previous modeling and observation studies, it was concluded that the emissions of primary air pollutants in Beijing were controlled successfully during the August 2008. In contrast to the primary pollutants, it was found that the mixing ratio of $\mathrm{O}_{3}$ increased from $28.2 \pm 27.2$ for the CareBeijing-2006 period to $40.1 \pm 25.1$ ppbv for August 2008 , which equals to an increase of $42.2 \%$. The sum of $\mathrm{O}_{3}$ and $\mathrm{NO}_{2}$ increased by $11.8 \%$, which means the reduced NO-O $\mathrm{O}_{3}$ titration cannot explain the contradictions between $\mathrm{O}_{3}$ and its precursors well. Nevertheless, the levels of total oxidant $\left(\mathrm{O}_{\mathrm{x}}=\mathrm{O}_{3}+\mathrm{NO}_{2}+1.5 \mathrm{NO}_{\mathrm{z}}\right)$ indeed reduced by $21.3 \%$, agreeing with the reduction of ozone precursors.

The photochemical responses of $\mathrm{O}_{3} / \mathrm{O}_{\mathrm{x}}$ to the reduction of the precursors were examined in two case studies with clear skies. On 3 August 2008, the hourly averages of $\mathrm{O}_{3}$ and $\mathrm{O}_{\mathrm{x}}$ mixing ratios reached their respective maxima, 135 and 169 ppbv, at 12:00 (local time $=\mathrm{GMT}+8: 00)$. An ozone production rate of $75.8 \mathrm{ppbv} \mathrm{h}^{-1}$ was estimated for the midday, implying that the precursors were still enough to sustain the $\mathrm{O}_{3}$ formation although the emissions were reduced significantly. During the course of $\mathrm{O}_{3} / \mathrm{O}_{\mathrm{x}}$ production and accumulation, there was an episode with spiky increases in the mixing ratios of $\mathrm{CO}, \mathrm{NMHCs}, \mathrm{NO}_{\mathrm{x}}$ as well as $\mathrm{NO}_{\mathrm{y}}$. The ob- served OPEx were 8.6 and 7.9 mole mole ${ }^{-1}$ before and after the spiky event, and dropped down to 3.6 mole mole $^{-1}$ during the episode. The declined OPEx for increases in $\mathrm{NO}_{\mathrm{x}}$ mixing ratio suggests that the $\mathrm{NO}_{\mathrm{x}}-\mathrm{NO}_{\mathrm{z}}$ conversion was enhanced and the photochemical condition was shifted toward VOC-sensitive regime. However, after the event, it was found that the concentrations of $\mathrm{O}_{3}$ increased with the increasing $\mathrm{NO}_{2} / \mathrm{NO}$ ratio, whereas the $\mathrm{NO}_{\mathrm{z}}$ concentrations leveled off when $\mathrm{NO}_{2} / \mathrm{NO}>8$. Consequently, the ratio of $\mathrm{O}_{3}$ to $\mathrm{NO}_{z}$ increased to above 10 , indicating the shift from VOC-sensitive regime to $\mathrm{NO}_{\mathrm{x}}$-sensitive regime. Such a backand-forth shift of the photochemical regime of $\mathrm{O}_{3}$ production necessitates further studies with sophisticated models. In contrast to the case of 3 August, the mixing ratios of $\mathrm{O}_{3}$ remained around 30-40 ppbv on 15 August in spite of the strong solar flux. An averaged OPEx of 1.2 mole mole $^{-1}$ was observed for 10:00-14:00, suggesting that the $\mathrm{OH}$ radicals were consumed very efficiently for the oxidation of $\mathrm{NO}_{\mathrm{x}}$. Besides the loss of $\mathrm{OH}$ radicals, it was inferred that the $\mathrm{O}_{3}$ production was inhibited by the extremely low level of NMHCs. The midday (11:00-13:00) mixing ratio of NMHCs was $6.1 \mathrm{ppbv}$ on 15 August, comparing with $23.2 \mathrm{ppbv}$ on 3 August. Thus, the formation of $\mathrm{RO}_{2}$ and, in turn, the recycling of $\mathrm{OH}$ should have been retarded.

According to the results of this study, it was concluded that the $\mathrm{O}_{3}$ production in Beijing should have been mitigated significantly during August 2008. The overall reduction in the mixing ratio of total oxidant was achieved for the successful control of the emissions of primary air pollutants. In particular, the reduction in NMHCs emissions was suggested to be the major cause of the mitigated $\mathrm{O}_{3}$ production during midday. On the other hand, as comparing with the summer of 2006, apparently higher mixing ratios of $\mathrm{O}_{3}$ were observed in August 2008. In addition to the declined $\mathrm{O}_{3}-\mathrm{NO}$ titration, changes in the composition of "total oxidant" were observed and suggested to be responsible for the contradictions between the $\mathrm{O}_{3}$ and $\mathrm{O}_{\mathrm{x}}$ mixing ratios.

Acknowledgements. The authors are grateful for the logistic support from the Peking University during the campaign period. The authors also gratefully acknowledge the NOAA Air Resources Laboratory (ARL) for the provision of the HYSPLIT transport and dispersion model and/or READY website (http://www.arl.noaa.gov/ready.html) used in this publication. This work was supported by the CAREBeijing 2008 (Campaign of Atmospheric Researches in Beijing and surrounding areas in 2008) research program, and was funded by the Academia Sinica and the National Science Council of Taiwan.

Edited by: M. Gauss 


\section{References}

An, X., Zhu, T., Wang, Z., Li, C., and Wang, Y.: A modeling analysis of a heavy air pollution episode occurred in Beijing, Atmos. Chem. Phys., 7, 3103-3114, doi:10.5194/acp-7-3103-2007, 2007.

Chang, C. C., Lo, S. J., Lo, J. G., and Wang, J. L.: Analysis of methyl tert-butyl ether (MTBE) in the atmosphere and implications as an exclusive indicator of automobile exhaust, Atmos. Environ., 37, 4747-4755, 2003.

Chou, C. C. K., Tsai, C. Y., Shiu, C. J., Liu, S. C., and Zhu, T.: Measurement of NOy during Campaign of Air Quality Research in Beijing 2006 (CAREBeijing-2006): Implications for the ozone production efficiency of $\mathrm{NO}_{\mathrm{x}}$, J. Geophys. Res.-Atmos., 114, D00G01, doi:10.1029/2008JD010446, 2009.

DeMore, W. B., Sander, S. P., Golden, D. M., Hampson, R. F., Kurylo, M. J., Howard, C. J., Ravishankara, A. R., Kolb, C. E., and Molina, M. J.: Chemical kinetics and photochemical data for use in stratospheric modeling, Jet Propul. Lab., 1997.

Donahue, N. M., Dubey, M. K., Mohrschladt, R., Kenneth, L. D., and Anderson, J. G.: High-pressure flow study of the reactions $\mathrm{OH}+\mathrm{NO}_{\mathrm{x}} \rightarrow \mathrm{HONO}_{\mathrm{x}}$, J. Geophys. Res., 102, 6159-6168, 1997.

Fehsenfeld, F. C., Dickerson, R. R., Hubler, G., Luke, W. T., Nunnermacker, L. J., Williams, E. J., Robberts, J. M., Calvert, J. G., Curran, C. M., Delany, A. C., Eubank, C. S., Fahey, D. W., Fried, A., Gandrud, B. W., Langford, A. O., Murphy, P. C., Norton, R. B., Pickering, K. E., and Ridley, B. A.: A ground-based intercomparison of $\mathrm{NO}, \mathrm{NO}_{\mathrm{x}}$, and $\mathrm{NO}_{\mathrm{y}}$ measurement techniques, $\mathrm{J}$. Geophys. Res., 92, 14710-14722, 1987.

Frost, G. J., Trainer, M., Allwine, G., Buhr, M. P., Calvert, J. G., Cantrell, C. A., Fehsenfeld, F. C., Goldan, P. D., Herwehe, J., Hubler, G., Kuster, W. C., Martin, R., McMillen, R. T., Montzka, S. A., Norton, R. B., Parrish, D. D., Ridley, B. A., Shetter, R. E., Walega, J. G., Watkins, B. A., Westberg, H. H., and Williams, E. J.: Photochemical ozone production in the rural southeastern United States during the 1990 Rural Oxidants in the Southern Environment (ROSE) program, J. Geophys. Res., 103, 2249122508, 1998.

Hofzumahaus, A., Rohrer, F., Lu, K., Hohn, B., Brauers, T., Chang, C.-C., Fuchs, H., Holland, F., Kita, K., Kondo, Y., Li, X., Lou, S., Shao, M., Zeng, L., Wahner, A., and Zhang, Y.: Amplified trace gas removal in the troposphere, Science, 324, 1702-1704, 2009.

Kleinman, L. I., Daum, P. H., Imre, D., Lee, Y.-N., Nunnermacker, L. J., Springston, S. R., Weinstein-Lloyd, J., and Rodolph, J.: Ozone production rate and hydrocarbon reactivity in 5 urban areas: A cause of high ozone concentration in Houston, Geophys. Res. Lett., 29, 1467, doi:10.1029/2001GL014569, 2002.

Levy II, H., Mahlman, J. D., Moxim, W. J., and Liu, S. C.: Tropospheric ozone: the role of transport, J. Geophys. Res., 90, 37533772, 1985.

Liu, J. F., Mu, Y. J., Zhang, Y. J., Zhang, Z. M., Wang, X. K., Liu, Y. J., and Sun, Z. Q.: Atmospheric levels of BTEX compounds during the 2008 Olympic Games in the urban area of Beijing, Sci. Total Environ., 408, 109-116, 2009.

Liu, S. C., Trainer, M., Fehsenfeld, F. C., Parrish, D. D., Williams, E. J., Fahey, D. W., Hubler, G., and Murphy, P. C.: Ozone production in the rural troposphere and the implications for regional and global ozone distributions, J. Geophys. Res., 92, 4191-4207, 1987.
Lu, K., Zhang, Y., Su, H., Brauers, T., Chou, C. C.-K., Hofzumahaus, A., Liu, S. C., Kita, K., Kondo, Y., Shao, M., Wahner, A., Wang, J. Wang, X., and Zhu, T.: Oxidant (O3+NO2) production processes and formation regimes in Beijing, J. Geophys. Res., 115, D07303, doi:10.1029/2009JD012714, 2010.

Mijling, B., van der A, R. J., Boersma, K. F., Van Roozendael, M., De Smedt, I., and Kelder, H. M.: Reductions of NO2 detected from space during the 2008 Beijing Olympic Games, Geophys. Res. Lett., 36, L13801, doi:10.1029/2009GL038943, 2009.

Molina, L. T., Molina, M. J., Slott, R. S., Kolb, C. E., Gbor, P. K., Meng, F., Singh, R. B., Galvez, O., Sloan, J. J., Anderson, W. P., Tang, X., Hu, M., Xie, S., Shao, M., Zhu, T., Zhang, Y. H., Gurjar, B. R., Artaxo, P. E., Oyola, P., Gramsch, E., Hidalgo, D., and Gertler, A. W.: Air Quality in Selected Megacities, J. Air Waste Manage. Assoc., 55, 1-73, 2004.

Sillman, S.: The use of NOy, H2O2, and HNO3 as indicators for ozone- $\mathrm{NO}_{\mathrm{X}}$-hydrocarbon sensitivity in urban locations, J. Geophys. Res., 100, 14175-14188, 1995.

Trainer, M., Parrish, D. D., Buhr, M .P., Norton, R. B., Fehsenfeld, F. C., Anlauf, K. G., Bottenheim, J. W., Tang, Y. Z., Wiebe, H . A., Roberts, J . M., Tanner, R. L., Newman,, L., Bowersox, V. C., Meagher, J. F., Olszyna, K. J., Rodgers, M. O., Wang, T., Berresheim, H., Demerjian, K. L., and Roychowdhury, U. K.: Correlation of $\mathrm{O}_{3}$ with $\mathrm{NO}_{\mathrm{y}}$ in photochemically aged air, J.Geophys. Res., 98, 2917-2925, doi:10.1029/92JD01910, 1993.

Wang, B., Shao, M., Lu, S. H., Yuan, B., Zhao, Y., Wang, M., Zhang, S. Q. and Wu, D.: Variation of ambient non-methane hydrocarbons in Beijing city in summer 2008, Atmos. Chem. Phys., 10, 5911-5923, doi:10.5194/acp-10-5911-2010, 2010a.

Wang, M., Zhu, T., Zheng, J., Zhang, R. Y., Zhang, S. Q., Xie, X. X., Han, Y. Q., and Li, Y.: Use of a mobile laboratory to evaluate changes in on-road air pollutants during the Beijing 2008 Summer Olympics, Atmos. Chem. Phys., 9, 8247-8263, doi:10.5194/acp-9-8247-2009, 2009a.

Wang, T. and Xie, S.: Assessment of traffic-related air pollution in the urban streets before and during the 2008 Beijing Olympic Games traffic control period, Atmos. Environ., 43, 5682-5690, 2009.

Wang, T., Ding, A. J., Gao, J., and Wu, W. S.: Strong ozone production in urban plumes from Beijing, China, Geophys. Res. Lett., 33, L21806, doi:10.1029/2006GL027689, 2006.

Wang, T., Nie, W., Gao, J., Xue, L. K., Gao, X. M., Wang, X. F., Qiu, J., Poon, C. N., Meinardi, S., Blake, D., Wang, S. L., Ding, A. J., Chai, F. H., Zhang, Q. Z., and Wang, W. X.: Air quality during the 2008 Beijing Olympics: secondary pollutants and regional impact, Atmos. Chem. Phys., 10, 7603-7615, doi:10.5194/acp-10-7603-2010, 2010b.

Wang, Y., Hao, J., McElroy, M. B., Munger, J. W., Ma, H., Chen, D., and Nielsen, C. P.: Ozone air quality during the 2008 Beijing Olympics-effectiveness of emission restrictions, Atmos. Chem. Phys., 9, 5237-5251, doi:10.5194/acp-9-5237-2009, 2009b.

Wang, S. X., Zhao, M., Xing, J.,Wu, Y., Zhou, Y., Lei, Y., He, K. B., Fu, L. X., Hao, J. M.: Quantifying the Air Pollutants Emission Reduction during the 2008 Olympic Games in Beijing, Environ. Sci. Technol., 44(7), 2490-2496, 2010c.

World Health Organization (WHO): Air qulity guidelines: global update 2005, WHO Regional Office for Europe, 2006.

Witte, J. C., Schoeberl, M. R., Douglass, A. R., Gleason, J. F., Krotkov, N. A., Gille, J. C., Pickering, K. E., and Livesey, N.: 
Satellite observations of changes in air quality during the 2008 Beijing Olympics and Paralympics, Geophys. Res. Lett., 36, L17803, doi:10.1029/2009GL039236, 2009.

Wood, E. C., Herndon, S. C., Onasch, T. B., Kroll, J. H., Canagaratna, M. R., Kolb, C. E., Worsnop, D. R., Neuman, J. A., Seila, R., Zavala, M., and Knighton, W. B.: A case study of ozone production, nitrogen oxides, and the radical budget in Mexico City, Atmos. Chem. Phys., 9, 2499-2517, doi:10.5194/acp-9-2499-2009, 2009.
Zhou, Y., Wu, Y., Yang, L., Fu, L., He, K., Wang, S., Hao, J., Chen,J., and Li, C.: The impact of transportation control measures on emission reductions during the 2008 Olympic Games in Beijing, China, Atmos. Environ., 44, 285-293, 2010. 